\title{
Application of Potential Phosphate-Solubilizing Bacteria and Organic Acids on Phosphate Solubilization from Phosphate Rock in Aerobic Rice
}

\author{
Qurban Ali Panhwar, ${ }^{1}$ Shamshuddin Jusop, ${ }^{1}$ Umme Aminun Naher, ${ }^{2,3}$ \\ Radziah Othman, ${ }^{1,2}$ and Mohd Ismail Razi ${ }^{2}$ \\ ${ }^{1}$ Department of Land Management, Faculty of Agriculture, Universiti Putra Malaysia, 43400 Serdang, Selangor, Malaysia \\ ${ }^{2}$ Institute of Tropical Agriculture, Universiti Putra Malaysia, 43400 Serdang, Selangor, Malaysia \\ ${ }^{3}$ Bangladesh Rice Research Institute, Gazipur, Bangladesh \\ Correspondence should be addressed to Radziah Othman; radziah@upm.edu.my
}

Received 1 July 2013; Accepted 22 August 2013

Academic Editors: P. Andrade and D. Zhou

Copyright (C) 2013 Qurban Ali Panhwar et al. This is an open access article distributed under the Creative Commons Attribution License, which permits unrestricted use, distribution, and reproduction in any medium, provided the original work is properly cited.

\begin{abstract}
A study was conducted at Universiti Putra Malaysia to determine the effect of phosphate-solubilizing bacteria (PSB) and organic acids (oxalic \& malic) on phosphate (P) solubilization from phosphate rock (PR) and growth of aerobic rice. Four rates of each organic acid $(0,10,20$, and $30 \mathrm{mM})$, and PSB strain (Bacillus sp.) were applied to aerobic rice. Total bacterial populations, amount of $\mathrm{P}$ solubilization, $\mathrm{P}$ uptake, soil $\mathrm{pH}$, and root morphology were determined. The results of the study showed significantly high $\mathrm{P}$ solubilization in PSB with organic acid treatments. Among the two organic acids, oxalic acid was found more effective compared to malic acid. Application of oxalic acid at $20 \mathrm{mM}$ along with PSB16 significantly increased soluble soil P $\left(28.39 \mathrm{mg} \mathrm{kg}^{-1}\right)$, plant P uptake (0.78 $\left.\mathrm{P} \mathrm{pot}^{-1}\right)$, and plant biomass $(33.26 \mathrm{mg})$. Addition of organic acids with PSB and PR had no influence on soil $\mathrm{pH}$ during the planting period. A higher bacterial population was found in rhizosphere $\left(8.78 \log _{10} \mathrm{cfu} \mathrm{g}^{-1}\right)$ compared to the nonrhizosphere and endosphere regions. The application of organic acids along with PSB enhanced soluble P in the soil solution, improved root growth, and increased plant biomass of aerobic rice seedlings without affecting soil $\mathrm{pH}$.
\end{abstract}

\section{Introduction}

Phosphate-solubilizing bacteria play a vital role in $\mathrm{P}$ solubilization by producing organic acids. Additionally, soils contain low molecular weight organic acids with one or more carboxylic groups and some of these acids like citrate, oxalate, acetate, malate, isocitrate, and tartrate. Plant root exudates and microorganisms produce organic acids and degrade complex organic molecules $[1,2]$. Organic acids perform many functions in the soil, such as root nutrient acquisition, mineral weathering, microbial chemotaxis, and metal detoxification. They play an important role in the mobilization of soil $\mathrm{P}$ and enhance $\mathrm{P}$ bioavailability $[3,4]$ with decreasing $\mathrm{P}$ adsorption and dissolution of insoluble $\mathrm{P}$ compounds such as $\mathrm{Ca}, \mathrm{Fe}$, and $\mathrm{Al}$ phosphates [3]. Organic acid exudation from roots is considered an important mechanism for plants to adapt in P-deficient environments [5]. The mechanism involves mobilization of unavailable $\mathrm{P}$ in the soil by organic acids [6]. The role of organic acids in P solubilization is highly soil dependent. On the contrary, one of the P solubilization mechanisms of microbes is the production of organic acids [7]. A number of organic acids such as lactic, citric, 2-ketogluconic, malic, oxalic, malonic, tartaric, and succinic have been identified that have chelating properties [8]. Evidence showed that addition of organic acids to soils increased plant $P$ uptake [9].

The PR is an alternative and natural source of P. The dissolution of $\mathrm{P}$ from $\mathrm{PR}$ is required for the availability of P. Many factors affect the dissolution of PR in soil such as, chemical composition, particle size of the PR, soil 


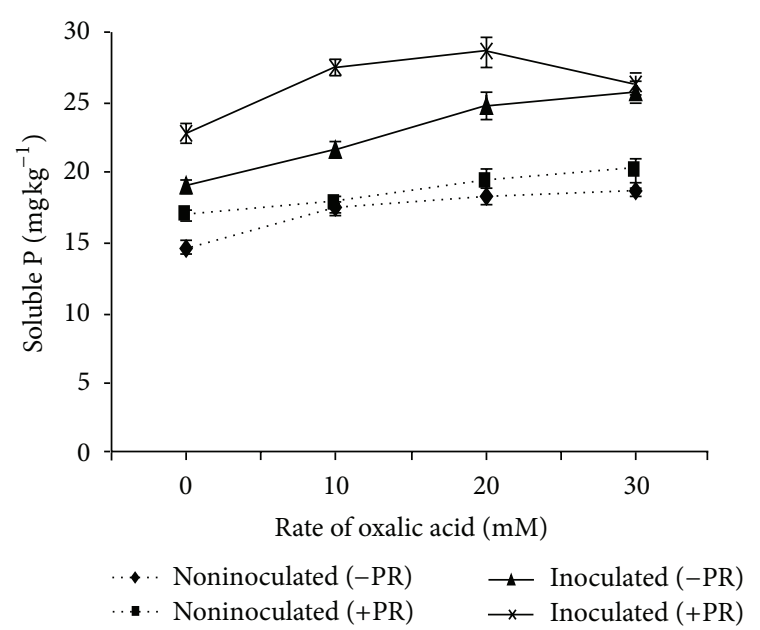

(a)

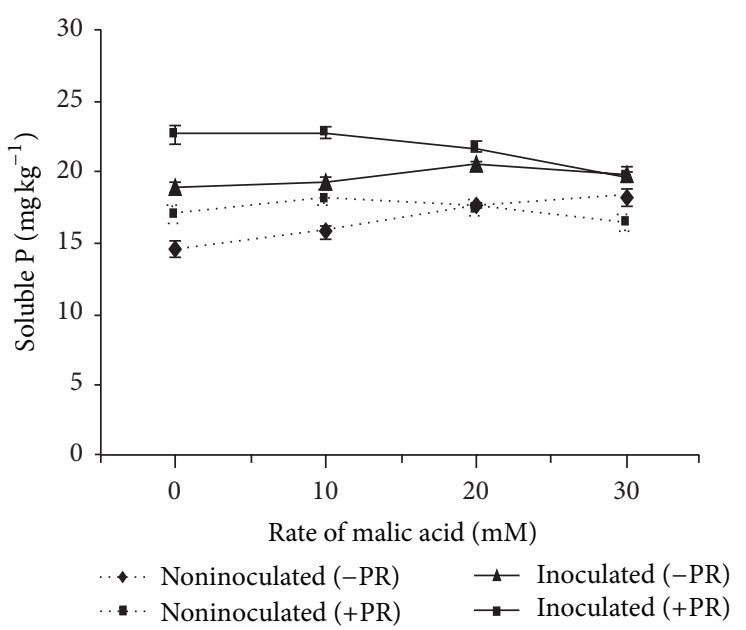

(b)

Figure 1: Effect of (a) oxalic acid (b) malic acid on P solubilization. Bars indicate standard error, $n=5$.

characteristics, $\mathrm{pH}, \mathrm{H}_{2} \mathrm{PO}_{4}{ }^{-}$, and $\mathrm{Ca}_{2}{ }^{+}[10]$. Dissolution of $\mathrm{PR}$ in acid soils can be explained as follows Khasawneh and Doll [11]:

$$
\mathrm{Ca}_{10}\left(\mathrm{PO}_{4}\right)_{6} \mathrm{~F}_{2}+12 \mathrm{H}^{+} \Longrightarrow 10 \mathrm{Ca}_{2}^{+}+6 \mathrm{H}_{2} \mathrm{PO}_{4}^{-}+2 \mathrm{~F}^{-}
$$

The equation specifies that the rate of dissolution is determined by the concentration of protons $\left(\mathrm{H}^{+}\right)$and the concentration of reaction products of $\mathrm{Ca}_{2}{ }^{+}$and $\mathrm{H}_{2} \mathrm{PO}_{4}$. In acidic soils, improvement of $\mathrm{P}$ nutrition to plants by direct application of PR as P fertilizer has been considered [12]. Phosphate rocks are affluent in calcium phosphate complexes and are soluble in acidic soil environments. Either microbial released organic acids or any acidic condition may favor $\mathrm{P}$ solubilization from PR. Hence, the present study was undertaken to determine the effect of different rates of organic acids with phosphate-solubilizing bacteria on $\mathrm{P}$ solubilization and their effect on growth of aerobic rice.

\section{Materials and Methods}

The experiment was conducted under in vitro condition. PSB16 (Bacillus sp.) isolated form aerobic rice rhizosphere [13], which was tested to produce indoleacetic acid, P solubilization, organic acids, and siderophore production in in vitro condition. The isolated strain was identified using 16S rRNA gene sequencing with accession number JX103827. Four rates each of oxalic and malic acids $(0,10,20$, and $30 \mathrm{mM})$ and PR (Christmas Island Rock Phosphate) at $60 \mathrm{~kg} \mathrm{P}_{2} \mathrm{O}_{5} \mathrm{ha}^{-1}$ were applied. The aerobic rice (var M9) was grown in the growth chamber for 40 days. Total bacterial populations, $\mathrm{P}$ solubilization, soil $\mathrm{pH}$, root morphology, and agronomic parameters were recorded after 40 days of growth.

2.1. Seed Surface Sterilization, Inoculation, and Growth of Rice Seedlings. The surface sterilized seven days old seedlings were transplanted into pots containing sterilized soil (500 g) with 4 uniform seedlings per pot. Plants were grown for 40 days in a growth chamber with $12 \mathrm{~h}$ light/dark cycle at $29 \pm$ $1^{\circ} \mathrm{C}$ temperature. Approximately $5 \times 10^{9} \mathrm{~mL}^{-1}$ of live washed bacterial cells of Bacillus sp. (PSB16) were used as inoculum in each bacterial treatment.

2.2. Determination of Bacterial Population, Plant Biomass, and Plant Tissue P. The total bacterial population was determined from rhizosphere, nonrhizosphere, and endosphere of aerobic rice plants. After harvest, soil available $\mathrm{P}$ was determined using Bray 2 [14] and total plant tissue $\mathrm{P}$ was analyzed by the wet digestion method [15].

2.3. Determination of Root Development. The root length $(\mathrm{cm})$, total surface $\left(\mathrm{cm}^{2}\right)$, and root volume $\left(\mathrm{cm}^{3}\right)$ were quantified using a scanner (Expression 1680, Epson) equipped with a $2 \mathrm{~cm}$ depth plexiglass tank $(20 \times 30 \mathrm{~cm})$ filled with $\mathrm{UP}_{2} \mathrm{O}$ [16].

2.4. Data Analysis. The experiment was conducted with the three factors in four replicates in a completely randomized design. Data obtained were statistically analyzed using the SAS software program (Version 9.2), and treatment means were compared using Tukey's test $(P<0.05)$.

\section{Results}

3.1. Effect of Organic Acids and PSB on P Solubilization and Plant $P$ Uptake. Higher values of solubilized $P$ were found in PSB inoculated treatments with organic acids application. Significantly high amount of solubilized P (31.51\%) was found in PSB inoculated treatments with $20 \mathrm{mM}$ oxalic acid (Figure 1(a)).

Between the two acids, $P$ solubilization was found higher in oxalic compared to malic acid at various rates. In malic acid treatments, higher $\mathrm{P}$ solubilization $\left(21.57 \mathrm{mg} \mathrm{kg}^{-1}\right)$ was observed with $10 \mathrm{mM}$ of malic acid in PSB inoculated treatments (Figure 1(b)). The amount of $\mathrm{P}$ solubilization and plant 


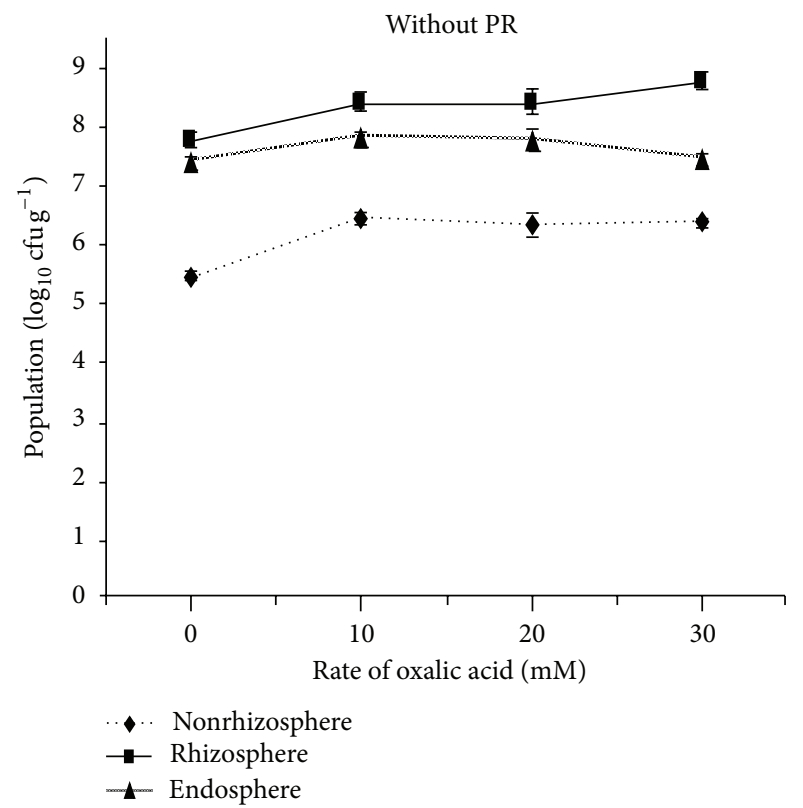

(a)

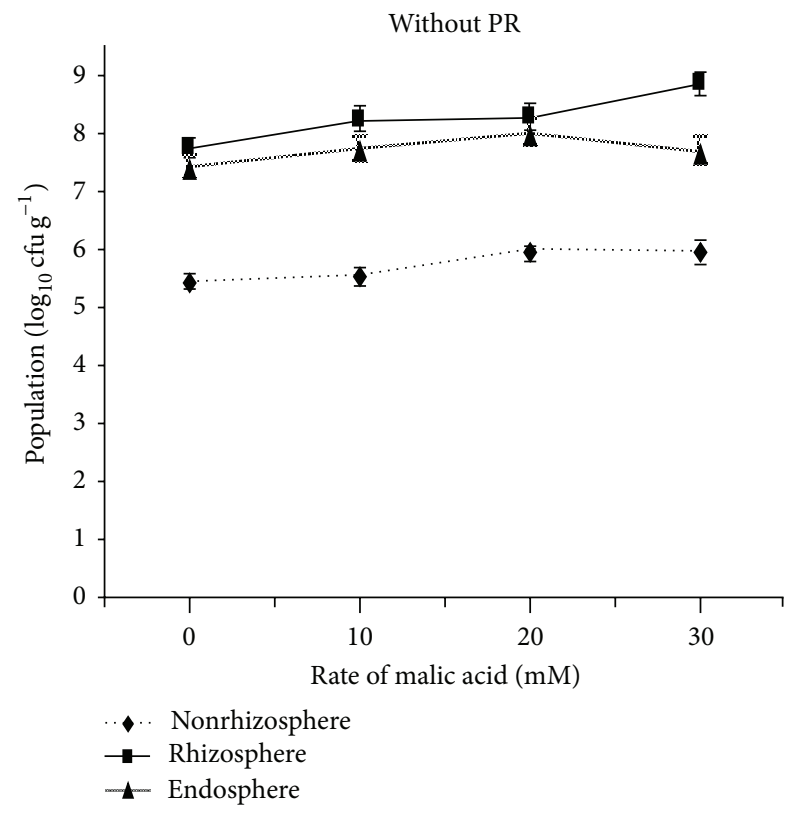

(c)

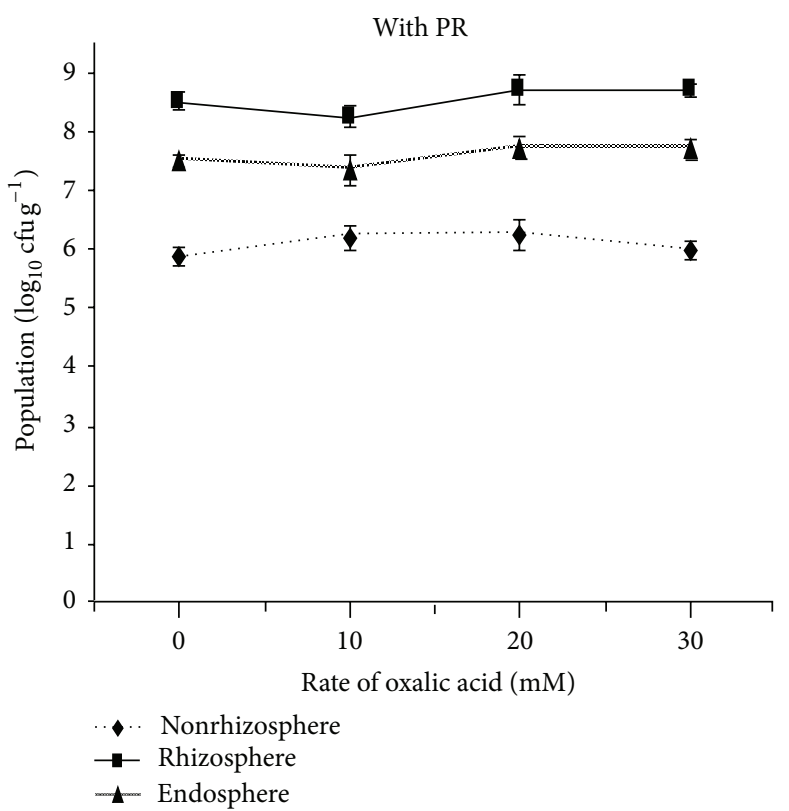

(b)

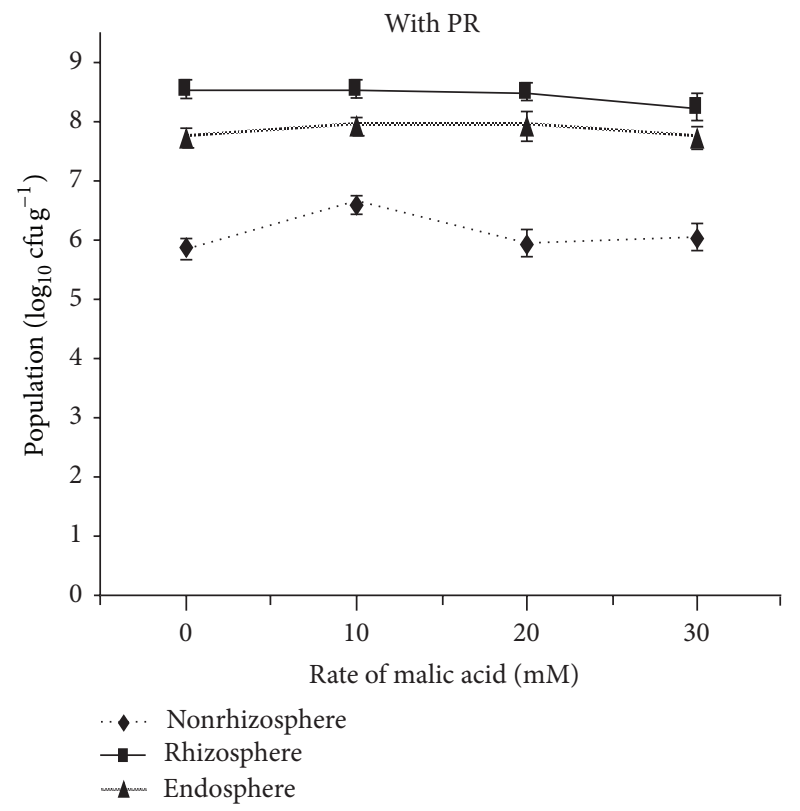

(d)

FIGURE 2: Effect of organic acids on PSB16 population, (a) oxalic acid without PR, (b) oxalic acid with PR, (c) malic acid without PR, (d) malic acid with PR. Bars indicate standard error, $n=5$.

P uptake differed with the bacterial inoculation and rate of organic acid application.

The application of organic acids also affected plant $\mathrm{P}$ uptake. Significantly higher plant P uptake was observed in PSB inoculated treatments added with organic acids (Table 1). Among both, the highest values of plant $\mathrm{P}$ uptake was found in PSB with oxalic acid at $20 \mathrm{mM}\left(0.78 \mathrm{P} \mathrm{pot}^{-1}\right)$ followed by $30 \mathrm{mM}\left(0.75 \mathrm{P} \mathrm{pot}^{-1}\right)$ concentrations, respectively.
3.2. Effect of Organic Acids on Bacterial Populations. The addition of organic acids influenced the bacterial population. Significantly $(P<0.05)$ higher populations were found in the rhizosphere $\left(8.78 \log _{10} \mathrm{cfu} \mathrm{g}^{-1}\right)$, while lower populations were found in nonrhizosphere soils $\left(5.40 \log _{10} \mathrm{cfu} \mathrm{g}^{-1}\right)$. The highest rhizosphere population $\left(8.65 \log _{10} \mathrm{cfu} \mathrm{g}^{-1}\right)$ was found in the $30 \mathrm{mM}$ oxalic acid treatment (Figures 2(a) and 2(b)). In the case of malic acid, a significantly higher population 


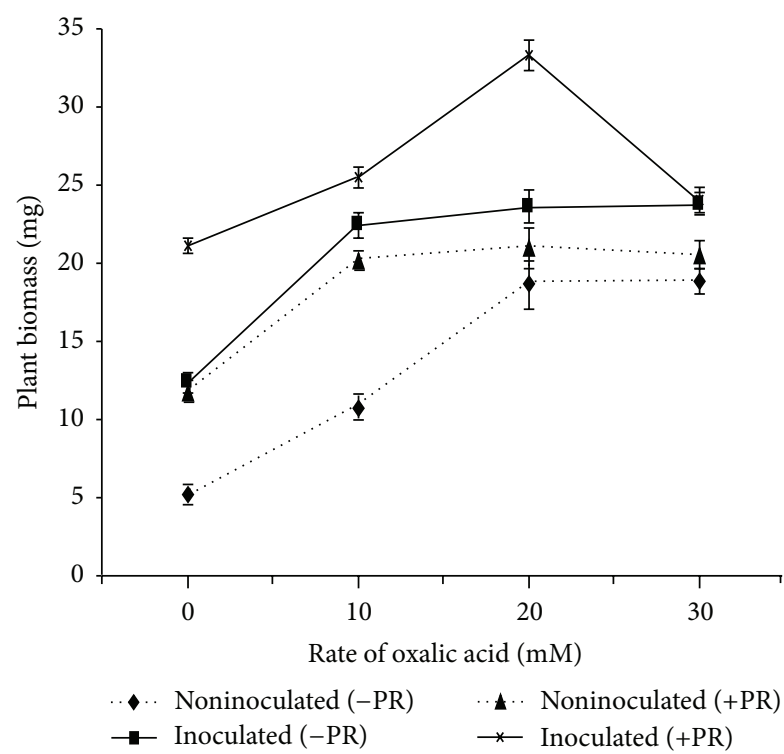

(a)

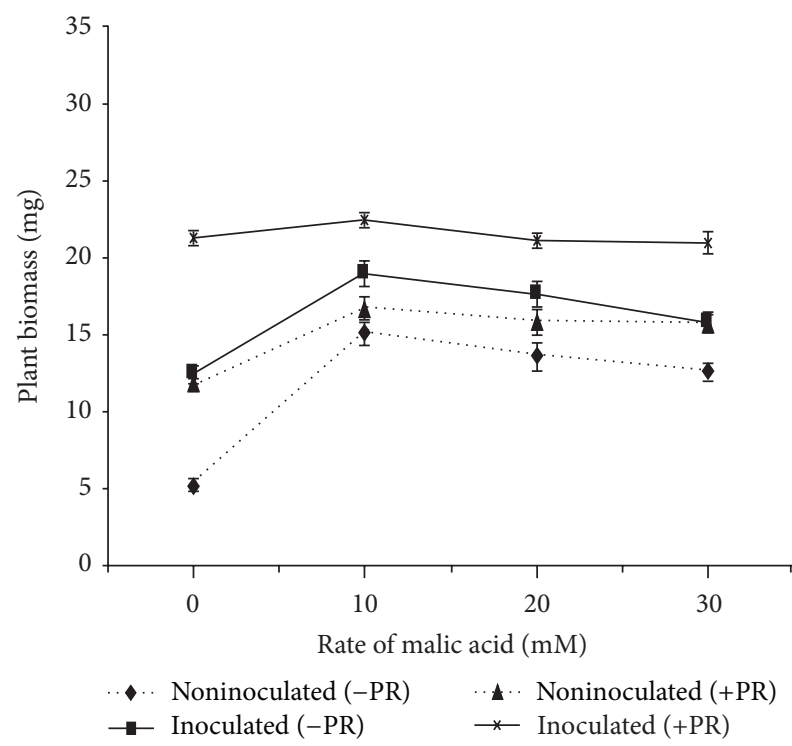

(b)

Figure 3: Effect of organic acids (a) oxalic acid (b) malic acid on plant biomass. Bars indicate standard error, $n=5$.

TABLE 1: Effect of organic acids on plant P uptake.

\begin{tabular}{|c|c|c|c|c|c|c|c|c|}
\hline \multirow{4}{*}{$\begin{array}{l}\text { Dose of } \\
\text { organic } \\
\text { acid }(\mathrm{mM})\end{array}$} & \multicolumn{8}{|c|}{ Plant $\mathrm{P}$ uptake $\left(\mathrm{mg} \mathrm{P}\right.$ pot $\left.^{-1}\right)$} \\
\hline & \multicolumn{4}{|c|}{ Oxalic acid } & \multicolumn{4}{|c|}{ Malic acid } \\
\hline & \multicolumn{2}{|c|}{ PSB noninoculated Treatments } & \multicolumn{2}{|c|}{ PSB inoculated Treatments } & \multicolumn{2}{|c|}{$\begin{array}{l}\text { PSB noninoculated Treatments } \\
\left(\mathrm{kg} \mathrm{ha}^{-1}\right)\end{array}$} & \multicolumn{2}{|c|}{ PSB inoculated Treatments } \\
\hline & 0 & 60 & 0 & 60 & 0 & 60 & 0 & 60 \\
\hline 0 & $0.21 \mathrm{e}$ & $0.29 b$ & $0.25 \mathrm{f}$ & $0.36 c$ & $0.21 d$ & $0.28 b$ & $0.23 \mathrm{e}$ & $0.33 c$ \\
\hline 10 & $0.24 \mathrm{~d}$ & $0.30 \mathrm{~b}$ & $0.29 \mathrm{e}$ & $0.48 \mathrm{~b}$ & $0.22 \mathrm{~d}$ & $0.29 b$ & $0.25 \mathrm{~d}$ & $0.39 \mathrm{a}$ \\
\hline 20 & $0.27 \mathrm{c}$ & $0.37 \mathrm{a}$ & $0.32 \mathrm{~d}$ & $0.78 \mathrm{a}$ & $0.24 \mathrm{~cd}$ & $0.34 \mathrm{a}$ & $0.27 \mathrm{~d}$ & $0.37 \mathrm{ab}$ \\
\hline 30 & $0.28 \mathrm{bc}$ & $0.39 \mathrm{a}$ & $0.37 \mathrm{c}$ & $0.75 \mathrm{a}$ & $0.26 c$ & $0.36 \mathrm{a}$ & $0.32 \mathrm{c}$ & $0.36 b$ \\
\hline
\end{tabular}

Means within the same column followed by the same letters are not significantly different at $P \leq 0.05$.

was found in the rhizosphere at $30 \mathrm{mM}$ acid without PR treatment $\left(8.78 \log _{10} \mathrm{cfu} \mathrm{g}^{-1}\right)$, whereas, in nonrhizosphere soil the highest population was recorded at $10 \mathrm{mM}$ acid without PR $\left(6.54 \log _{10} \mathrm{cfu} \mathrm{g}^{-1}\right)$. However, the endosphere population was not influenced by the addition of organic acids (Figures 2(c) and 2(d)). Solubilization of P by PSB in the rhizosphere is a continuous process. The addition of organic acids had a positive influence on the PSB16 population. A higher population was found with the addition of organic acids combined with PR. The changes in PSB population occurred mostly in the nonrhizosphere region, and it becomes lower with the addition of oxalic acid treatments.

\subsection{Effect of Organic Acids and PSB on Plant Height and Plant}

Biomass. There were significant differences found between the organic acids and their various rates. Significantly $(P<$ 0.05) high values of plant height were observed in the PSB inoculated treatments. Among both acids, the highest plant height $(23 \mathrm{~cm})$ was observed in oxalic acid $(20 \mathrm{mM})$ with PR and PSB16, compared to malic acid (Table 2).
Inoculation of PSB with PR showed higher plant biomass than noninoculated treatments (Figure 3). Application of organic acids with PSB16 and PR significantly increased the plant biomass, and comparatively oxalic acid produced higher plant biomass than malic acid. The highest plant biomass $(33.26 \mathrm{mg}$ ) was recorded in PSB inoculated plants at $20 \mathrm{mM}$ oxalic acid concentration with PR (Figure 3(a)). Application of malic acid increased biomass at $10 \mathrm{mM}$ and showed no further increase at higher levels (Figure 3(b)).

3.4. Effect of Organic Acids and PSB on Soil pH. The soil pH during the planting period was not much affected (Figures 4 and 5). Slightly lower $\mathrm{pH}$ values were observed in PSB inoculated compared to noninoculated treatments. Among both acids a higher decrease in $\mathrm{pH}$ values was found with the addition of malic acid with PSB inoculation. The instability of organic acid or soil buffering system might have an effect in regulating the soil $\mathrm{pH}$. However, slight decreases were found which could be due to the influence of organic acids to change $\mathrm{pH}$ in the rhizospheric regions. 


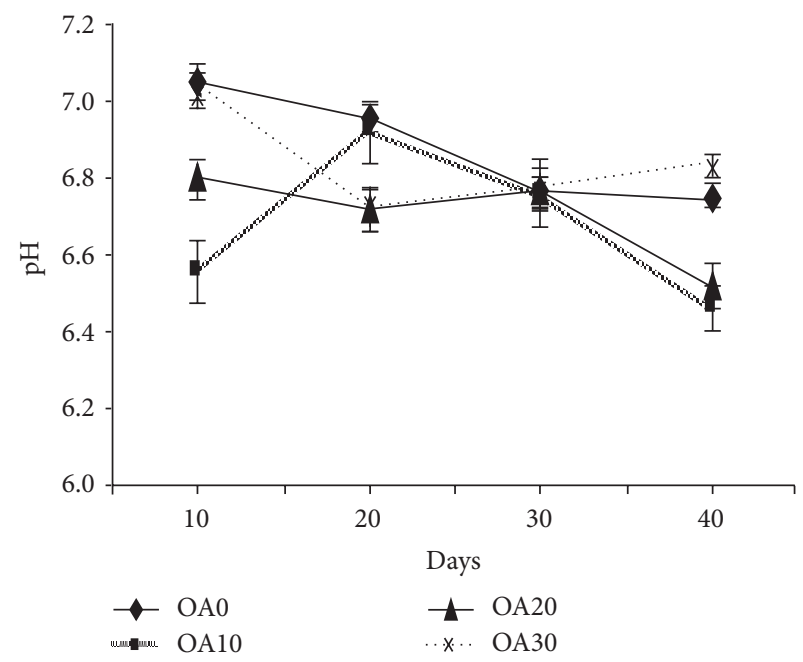

(a) Noninoculated without PR

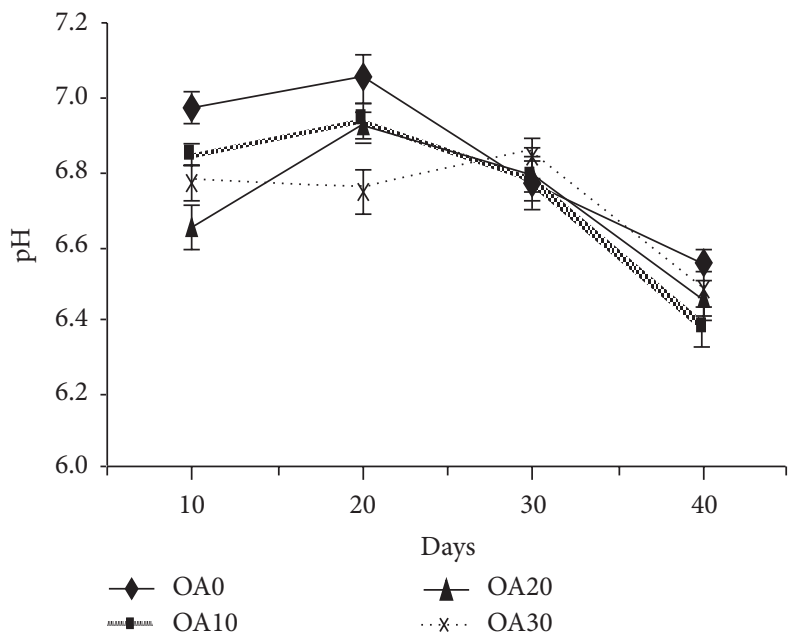

(c) Noninoculated with PR

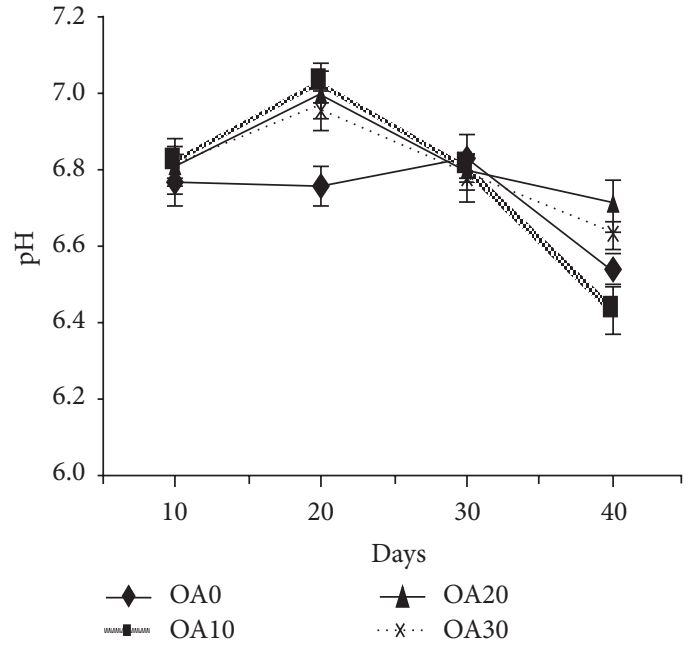

(b) PSB inoculated without PR

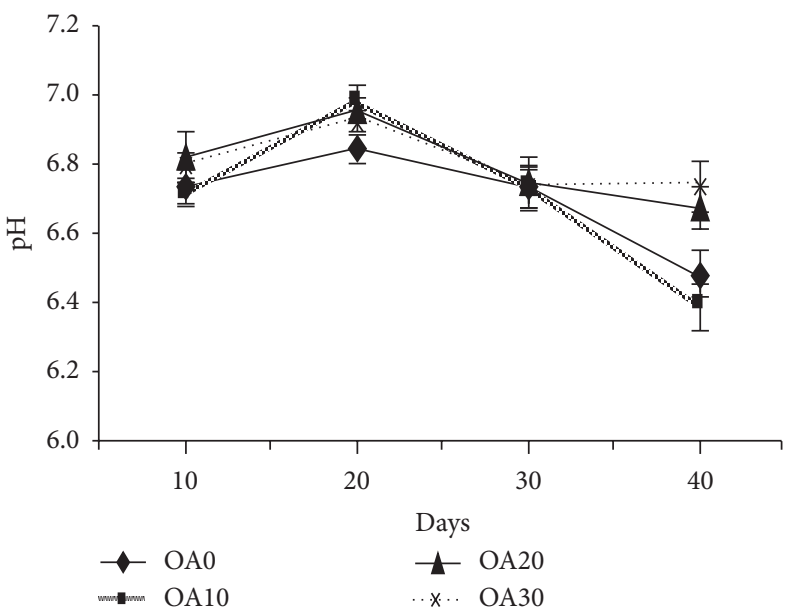

(d) PSB inoculated with PR

Figure 4: Effect of oxalic acid (OA) on soil pH. Bars indicate standard error, $n=5$.

TABLE 2: Effect of organic acids on plant height of aerobic rice seedling.

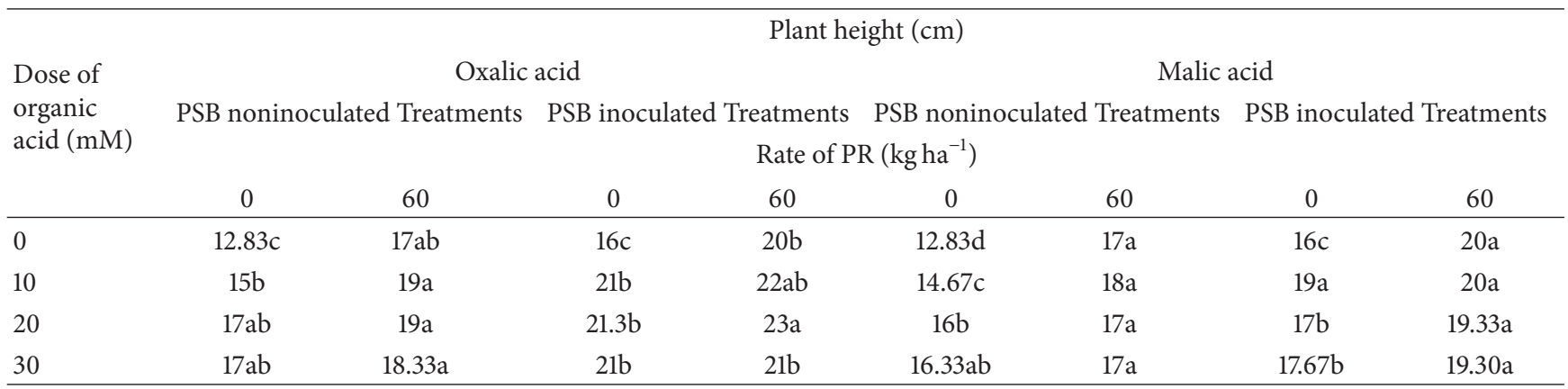

Means within the same column followed by the same letters are not significantly different at $P \leq 0.05$.

3.5. Effect of Organic Acids and PSB on Root Development. Root development in aerobic rice was influenced by the application of organic acids, PSB, and PR. The highest root length, surface area, and root volume were found in treatments with organic acids, PR, and PSB16 inoculations (Figures 6 and 7). Among both acids, oxalic acid produced higher root growth. Significantly $(P<0.05)$ higher root length $(7.64 \mathrm{~cm})$, root surface area $\left(2.36 \mathrm{~cm}^{2}\right)$ and root volume $\left(0.11 \mathrm{~cm}^{3}\right)$ were found in oxalic acid at $20 \mathrm{mM}$ with PR and PSB16 inoculated treatments (Figures 6 and 7). External application of organic 


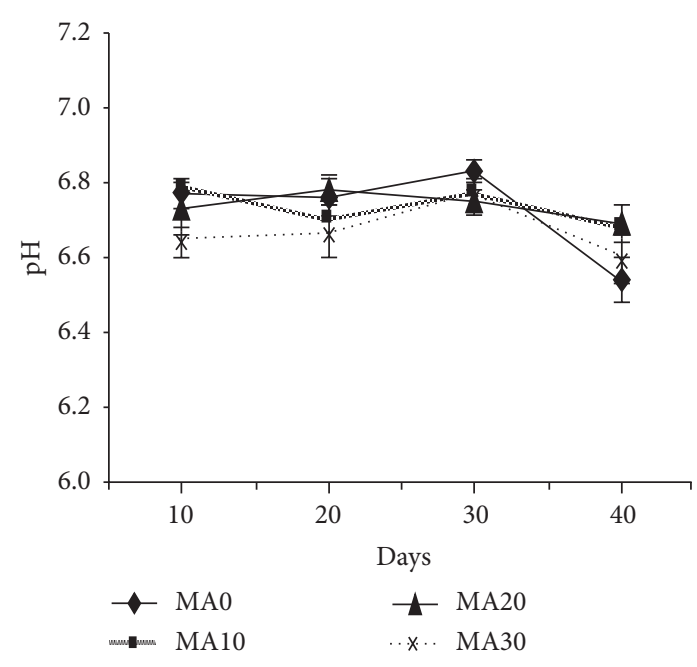

(a) Noninoculated without PR

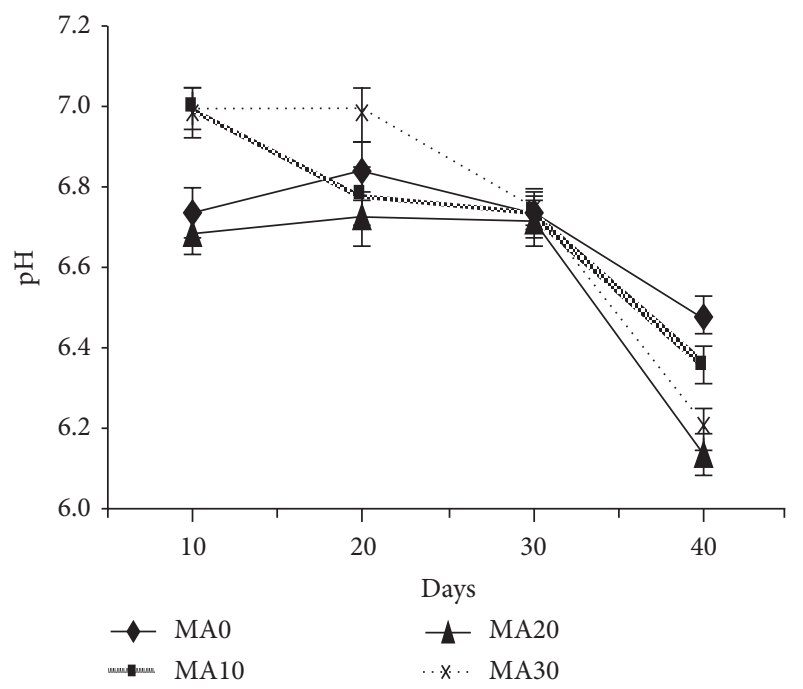

(c) Noninoculated with PR

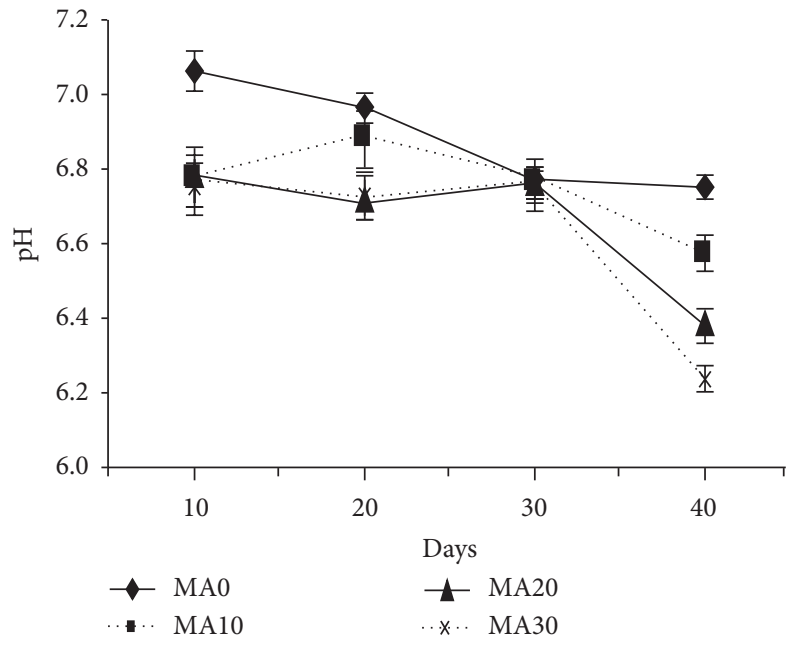

(b) PSB inoculated without PR

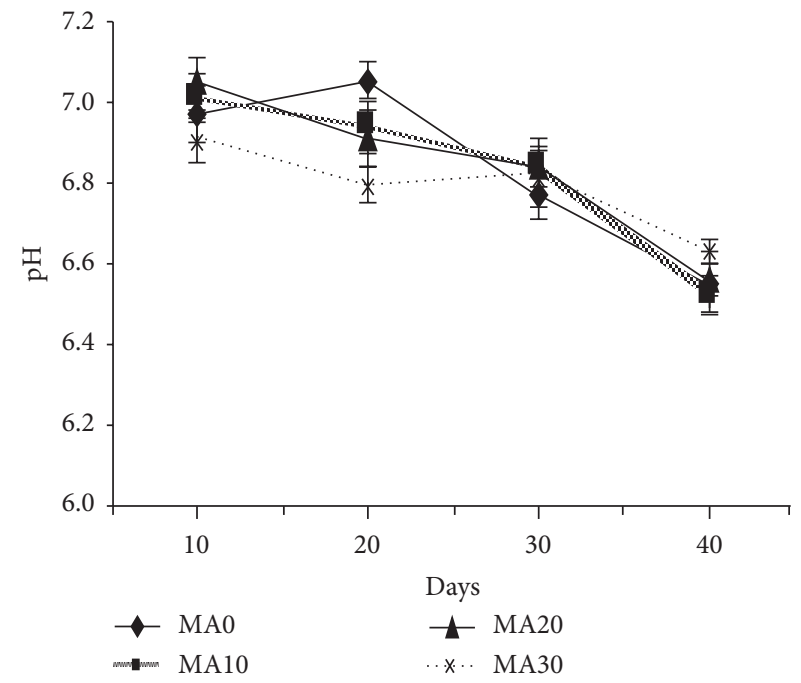

(d) PSB inoculated with PR

FIgURE 5: Effect of malic acid (MA) on soil pH. Bars indicate standard error, $n=5$.

acids along with PSB enhanced soluble P in the solution and this had a positive impact on root growth.

\section{Discussion}

The PSB and organic acid solubilized higher values of $\mathrm{P}$ in aerobic rice. However, high amounts of solubilized P were observed in PSB inoculated with oxalic acid application. These results are in agreement with the findings of Asea et al. [17] who noted that an application of oxalic acid was effective for P solubilization. Similar results were observed by Wei et al. [18] who observed that oxalic acids are more prominent in solubilizing P compared to other organic acids. Strong binding abilities of oxalic and citric acids have been proven as the most competent agents to solubilize soil P [1]. The application of organic acids also affected plant $\mathrm{P}$ uptake.

The bacterial population was influenced with the addition of organic acids. The population was varied in both organic acids at different rates in plant rhizosphere and nonrizosphere population. Thus, it might be due direct contact of the acids in soil and could be able to perform prominently for the P solubilization. Moreover, solubilization of P by PSB in the rhizosphere is a continuous process. PSB solubilize insoluble P by several mechanisms such as acidification, chelation, and exchange reactions [19]. It was reported that PSB solubilized PR as well as di-calcium phosphate and about 20-50 times less organic acids secreted by PSB were required for P solubilization. Furthermore, PSB strains (Citrobacter koseri and Bacillus coagulans) have been proven to solubilize PR with many organic acids [20]. The release of P is extremely soil dependent with higher concentrations of organic acids required to mobilize major quantities of $\mathrm{P}$ into the soil solution [21].

The changes in PSB population occurred mostly in the nonrhizosphere region, and it becomes lower with the addition of oxalic acid treatments. This could happen due to 


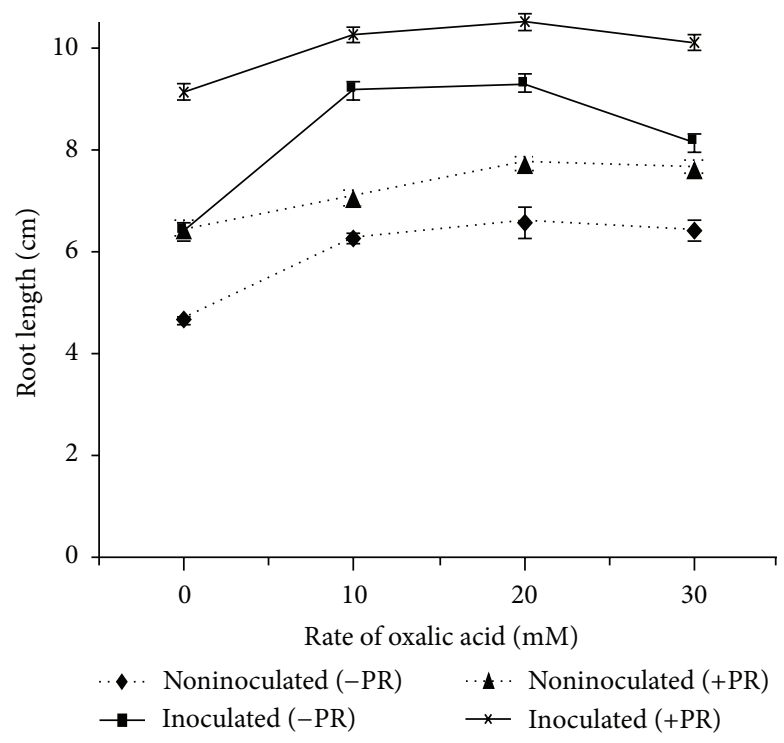

(a)

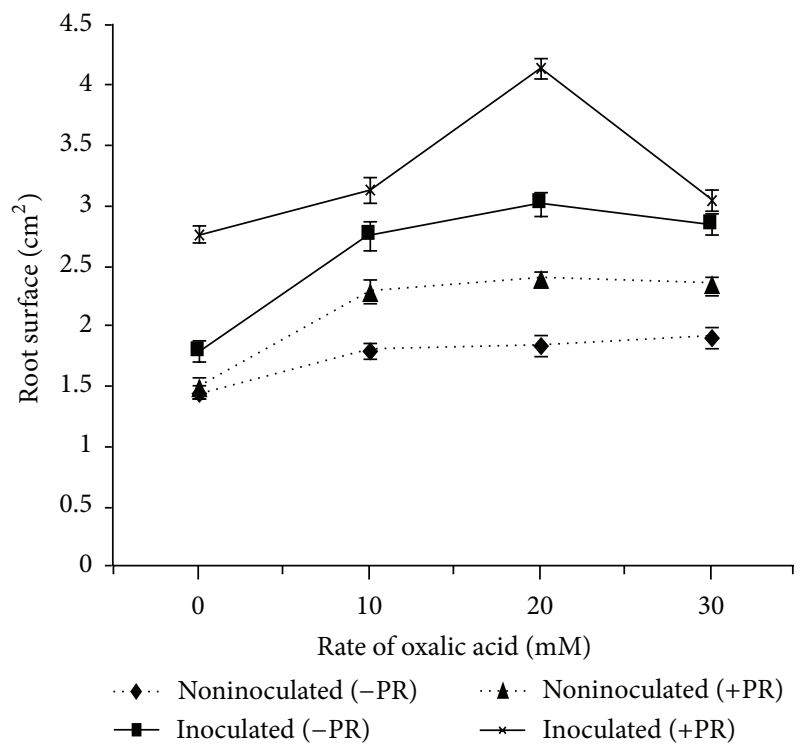

(b)

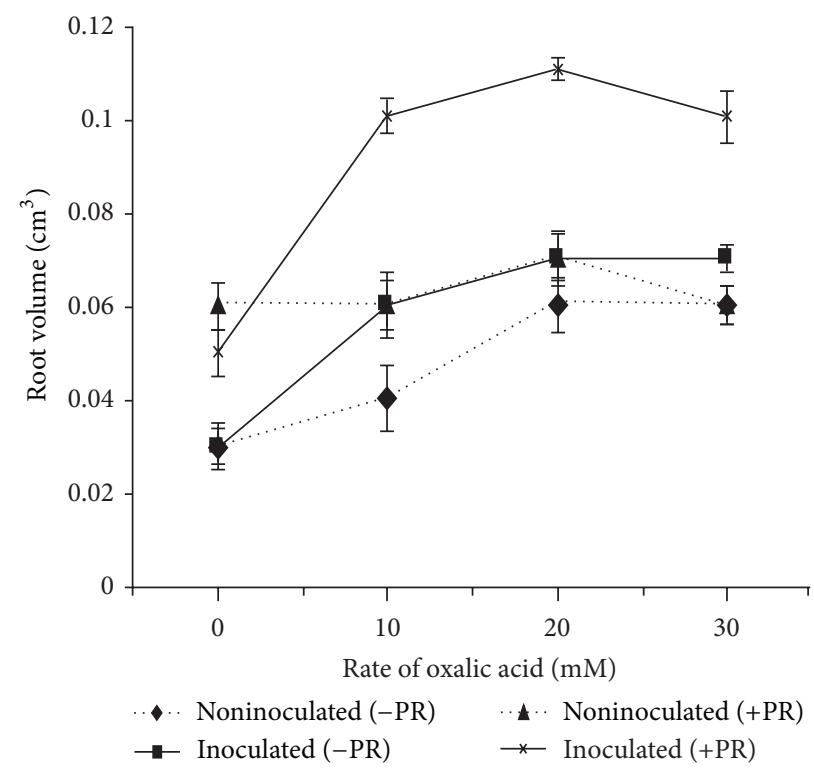

(c)

FiguRE 6: Effect of oxalic acid on (a) root length, (b) root surface, and (c) Root volume. Bars indicate standard error, $n=5$.

the transfer of bacteria from the nonrhizosphere to the rhizosphere zone, as the rhizospheric zone is a source of organic carbon which is needed for microbial activity. Cannon et al. [22] pointed out that there was a significant increase in soil and plant tissue $\mathrm{P}$ where oxalic acid was applied and is readily degraded by microorganisms. The increase in soluble $\mathrm{P}$ in the solution and increase in plant biomass proved that application of organic acids along with PSB16 had a positive effect on plant and microbial growth.

The organic acids with PSB16 and PR increased the plant biomass. Besides P solubilization activity, PSB liberates phytohormone (IAA) that might have an influence on root growth. The extensive root system increased nutrient uptake from the surroundings which increased plant biomass [23]. The organic acids serve as a source of carbon for the microorganisms, and subsequently, affect the rhizosphere microbial population as well as plant growth [24].

The application of organic acid, PSB16, and PR slightly affected the soil $\mathrm{pH}$ values. This could be due to the soil buffering system, and it did not affect much the change of soil $\mathrm{pH}$. The slight reductions were observed in the rhizosphere, that could be due to the influence of organic acid applications. These results are consistent with the findings of Zeng et al. [25] who reported that the organic acid have significant positive correlation $\mathrm{pH}$ of the rhizosphere of rice plants furthermore, when PR is added to soil (alfisols), mostly organic acids brought about a drop in $\mathrm{pH}$ for $\mathrm{P}$ released [26].

The plant root development in aerobic rice was affected by the application of organic acids, PSB, and PR. External application of organic acids along with PSB enhanced soluble 


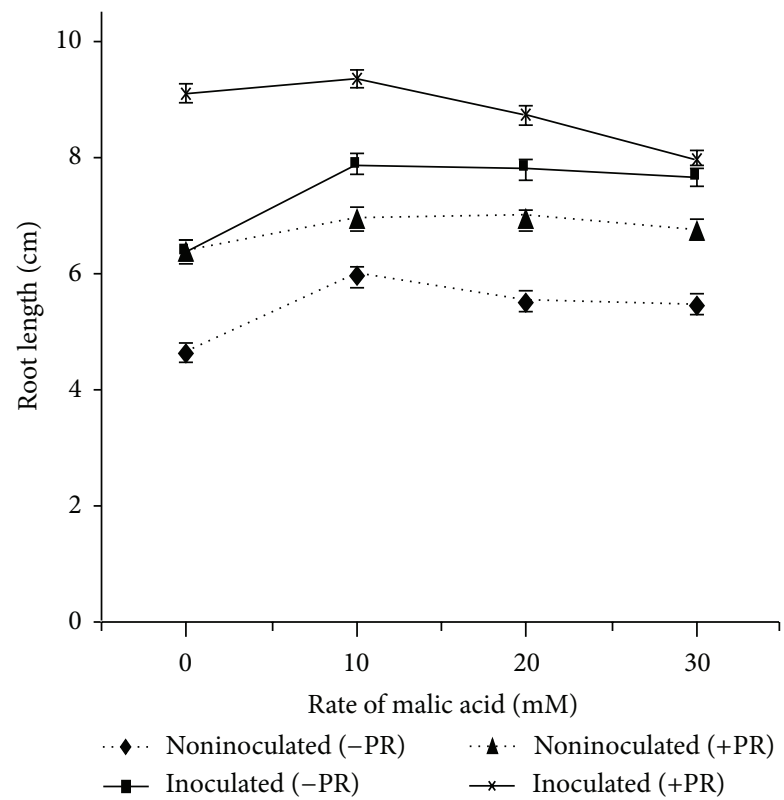

(a)

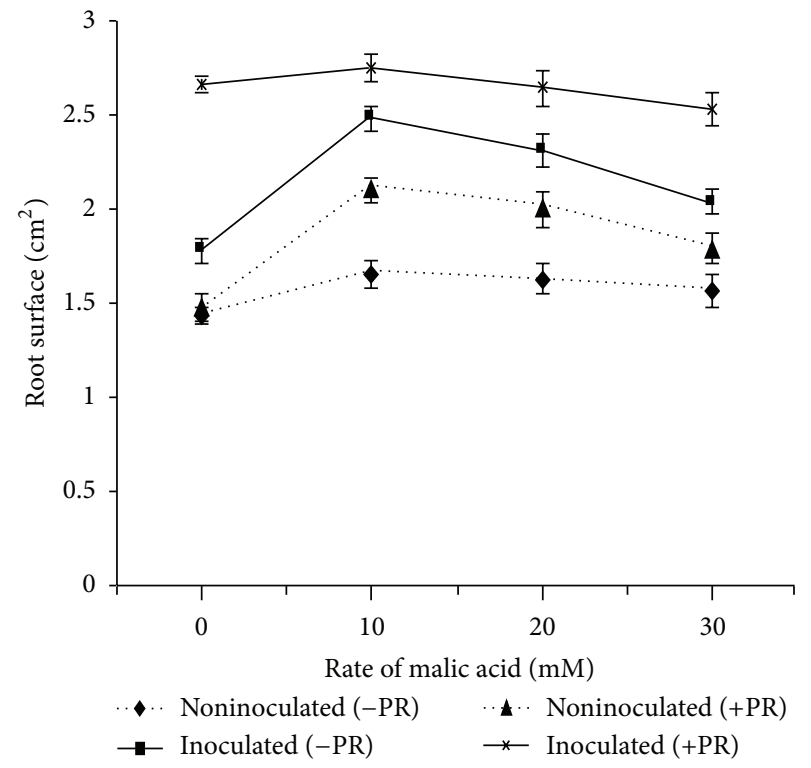

(b)

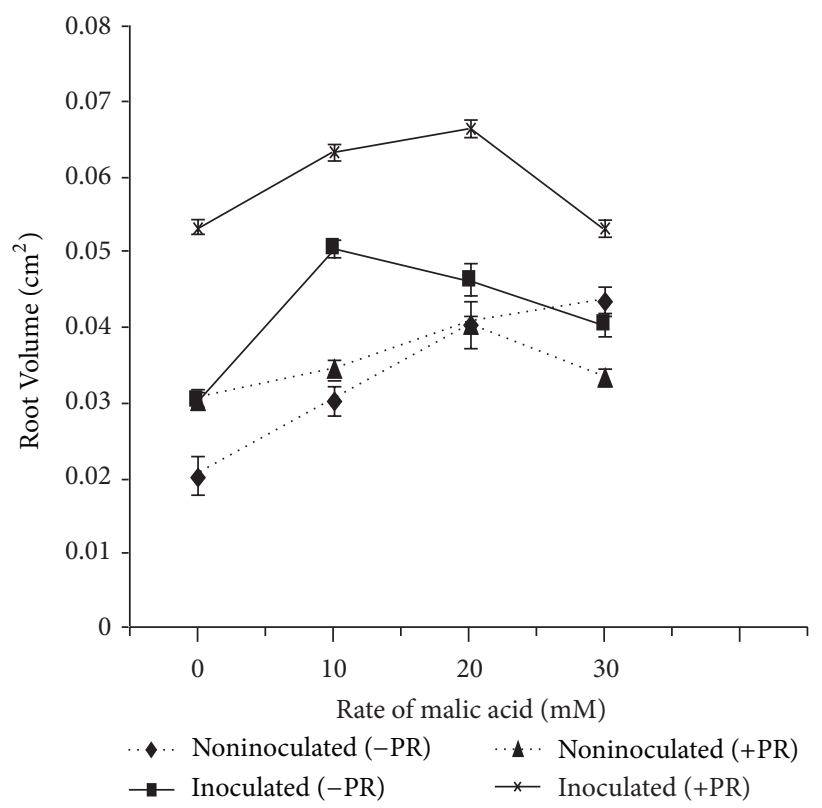

(c)

FIGURE 7: Effect of malic acid on (a) root length, (b) root surface, and (c) root volume. Bars indicate standard error, $n=5$.

$\mathrm{P}$ in the solution and this had a positive impact on root growth. These results are in agreement with the findings of Srivastava et al. [27] who reported that addition of organic acid with PR brought release of $\mathrm{P}$ and showed positive effect on plant growth. Moreover, Hoffland et al. [28] found organic acids in root exudates which were highly efficient in increasing P release from PR. The root development and plant biomass were correlated with the higher availability of P; moreover, PSB application may also have some other beneficial effects like phytohormones production.

\section{Conclusion}

The application of organic acids and PSB16 showed differences in P solubilization from PR. Among both acids, oxalic acid showed better results when compared to malic acid. The PSB16 population and soil $\mathrm{pH}$ were not affected by the application of organic acids. Application of oxalic acid at $20 \mathrm{mM}$ along with PSB16 significantly increased soluble P release from PR. In conclusion, addition of organic acids with PSB increased the solubility of PR and had a significant 
effect on the growth of aerobic rice. However, at the higher concentration of oxalic acid application may present a health risk, especially for children.

\section{Acknowledgments}

The authors are grateful to Universiti Putra Malaysia and Longterm Research Grant Scheme (LRGS) fund for Food Security providing the financial support for this project.

\section{References}

[1] D. L. Jones, "Organic acids in the rhizosphere-a critical review," Plant and Soil, vol. 205, no. 1, pp. 25-44, 1998.

[2] R. S. Yadav and J. C. Tarafdar, "Phytase and phosphatase producing fungi in arid and semi-arid soils and their efficiency in hydrolyzing different organic P compounds," Soil Biology and Biochemistry, vol. 35, no. 6, pp. 745-751, 2003.

[3] N. S. Bolan, R. Naidu, S. Mahimairaja, and S. Baskaran, "Influence of low-molecular-weight organic acids on the solubilization of phosphates," Biology and Fertility of Soils, vol. 18, no. 4, pp. 311-319, 1994.

[4] L. Ström, A. G. Owen, D. L. Godbold, and D. L. Jones, "Organic acid mediated $\mathrm{P}$ mobilization in the rhizosphere and uptake by maize roots," Soil Biology and Biochemistry, vol. 34, no. 5, pp. 703-710, 2002.

[5] C. R. Chen, L. M. Condron, and Z. H. Xu, "Impacts of grassland afforestation with coniferous trees on soil phosphorus dynamics and associated microbial processes: a review," Forest Ecology and Management, vol. 255, no. 3-4, pp. 396-409, 2008.

[6] Y. Wang, Y. He, H. Zhang, J. Schroder, C. Li, and D. Zhou, "Phosphate mobilization by citric, tartaric, and oxalic acids in a clay loam ultisol," Soil Science Society of America Journal, vol. 72, no. 5, pp. 1263-1268, 2008.

[7] B. B. Jana, "Distribution pattern and role of phosphate solubilizing bacteria in the enhancement of fertilizer value of rock phosphate in aquaculture ponds. State-of-the-art," in First International Meeting on Microbial Phosphate Solubilization, E. Velázquez and C. Rodríguez-Barrueco, Eds., pp. 229-238, Springer, Salamanca, Spain, 2002.

[8] R. M. N. Kucey, H. H. Janzen, and M. E. Leggett, "Microbially mediated increases in plant-available phosphorus," Advances in Agronomy, vol. 42, pp. 199-228, 1989.

[9] N. V. Hue, "Effects of organic acids/anions on P sorption and phytoavailability in soils with different mineralogies," Soil Science, vol. 152, no. 6, pp. 463-471, 1991.

[10] M. M. Hanafi, J. K. Syers, and N. S. Bolan, "Leaching effect on the dissolution of two phosphate rocks in acid soils," Soil Science Society of America Journal, vol. 56, no. 4, pp. 1325-1330, 1992.

[11] F. E. Khasawneh and E. C. Doll, "The use of phosphate rock for direct application to soils," Advances in Agronomy, vol. 30, pp. 159-206, 1979.

[12] S. S. S. Rajan, J. H. Watkinson, and A. G. Sinclair, "Phosphate rocks for direct application to soils," Advances in Agronomy, vol. 57, pp. 77-159, 1996.

[13] Q. A. Panhwar, R. Othman, Z. A. Rahman, S. Meon, and M. R. Ismail, "Isolation and characterization of phosphatesolubilizing bacteria from aerobic rice," African Journal of Biotechnology, vol. 11, no. 11, pp. 2711-2719, 2012.
[14] R. H. Bray and L. T. Kurtz, "Determination of total, organic, and available forms of phosphorus in soils," Soil Science, vol. 59, pp. 39-45, 1945.

[15] J. L. Havlin and P. N. Soltanpour, "A nitric acid plant tissue digest method for use with inductively coupled plasma spectrometry," Communications in Soil Science and Plant Analysis, vol. 1, pp. 969-980, 1980.

[16] H. El Zemrany, S. Czarnes, P. D. Hallett, S. Alamercery, R. Bally, and L. J. Monrozier, "Early changes in root characteristics of maize (Zea mays) following seed inoculation with the PGPR Azospirillum lipoferum CRT1," Plant and Soil, vol. 291, no. 1-2, pp. 109-118, 2007.

[17] P. E. A. Asea, R. M. N. Kucey, and J. W. B. Stewart, "Inorganic phosphate solubilization by two Penicillium species in solution culture and soil," Soil Biology and Biochemistry, vol. 20, no. 4, pp. 459-464, 1988.

[18] L. L. Wei, C. R. Chen, and Z. H. Xu, "The effect of lowmolecular-weight organic acids and inorganic phosphorus concentration on the determination of soil phosphorus by the molybdenum blue reaction," Biology and Fertility of Soils, vol. 45, no. 7, pp. 775-779, 2009.

[19] A. Zaidi, M. S. Khan, M. Ahemad, M. Oves, and P. A. Wani, "Recent advances in plant growth promotion by phosphatesolubilizing microbes," in Microbial Strategies for Crop Improvement, M. S. Khan, A. Zaidi, and J. Musarrat, Eds., pp. 15-24, Springer, Berlin, Germany, 2009.

[20] P. Gyaneshwar, G. N. Kumar, and L. J. Parekh, "Effect of buffering on the phosphate-solubilizing ability of microorganisms," World Journal of Microbiology and Biotechnology, vol. 14, no. 5, pp. 669-673, 1998.

[21] D. L. Jones and P. R. Darrah, "Re-sorption of organic compounds by roots of Zea mays L. and its consequences in the rhizosphere. III. Characteristics of sugar influx and efflux," Plant and Soil, vol. 178, no. 1, pp. 153-160, 1996.

[22] J. P. Cannon, E. B. Allen, M. F. Allen, L. M. Dudley, and J. J. Jurinak, "The effects of oxalates produced by Salsola tragus on the phosphorus nutrition of Stipa pulchra," Oecologia, vol. 102, no. 3, pp. 265-272, 1995.

[23] U. A. Naher, R. Othman, Z. H. Shamsuddin, H. M. Saud, M. R. Ismail, and K. A. Rahim, "Effect of root exuded specific sugars on biological nitrogen fixation and growth promotion in rice (Oryza sativa)," Australian Journal of Crop Science, vol. 5, no. 10, pp. 1210-1217, 2011.

[24] U. A. Naher, O. Radziah, M. S. Halimi, Z. H. Shamsuddin, and I. M. Razi, "Effect of inoculation on root exudates carbon sugar and amino acids production of different rice varieties," Research Journal of Microbiology, vol. 3, no. 9, pp. 580-587, 2008.

[25] F. Zeng, S. Chen, Y. Miao, F. Wu, and G. Zhang, "Changes of organic acid exudation and rhizosphere $\mathrm{pH}$ in rice plants under chromium stress," Environmental Pollution, vol. 155, no. 2, pp. 284-289, 2008.

[26] J. E. Cunningham and C. Kuiack, "Production of citric and oxalic acids and solubilization of calcium phosphate by Penicillium bilaii," Applied and Environmental Microbiology, vol. 58, no. 5, pp. 1451-1458, 1992.

[27] S. Srivastava, M. T. Kausalya, G. Archana, O. P. Rupela, and G. Naresh-Kumar, "Efficacy of organic acid secreting bacteria in solubilization of rock phosphate in acidic alfisols," in First International Meeting on Microbial Phosphate Solubilization, 1619 July, 2002, E. Velázquez and C. Rodríguez-Barrueco, Eds., pp. 117-124, Springer, Salamanca, Spain, 2003. 
[28] E. Hoffland, G. R. Findenegg, and J. A. Nelemans, "Solubilization of rock phosphate by rape-II: local root exudation of organic acids as a response to P-starvation," Plant and Soil, vol. 113, no. 2, pp. 161-165, 1989. 

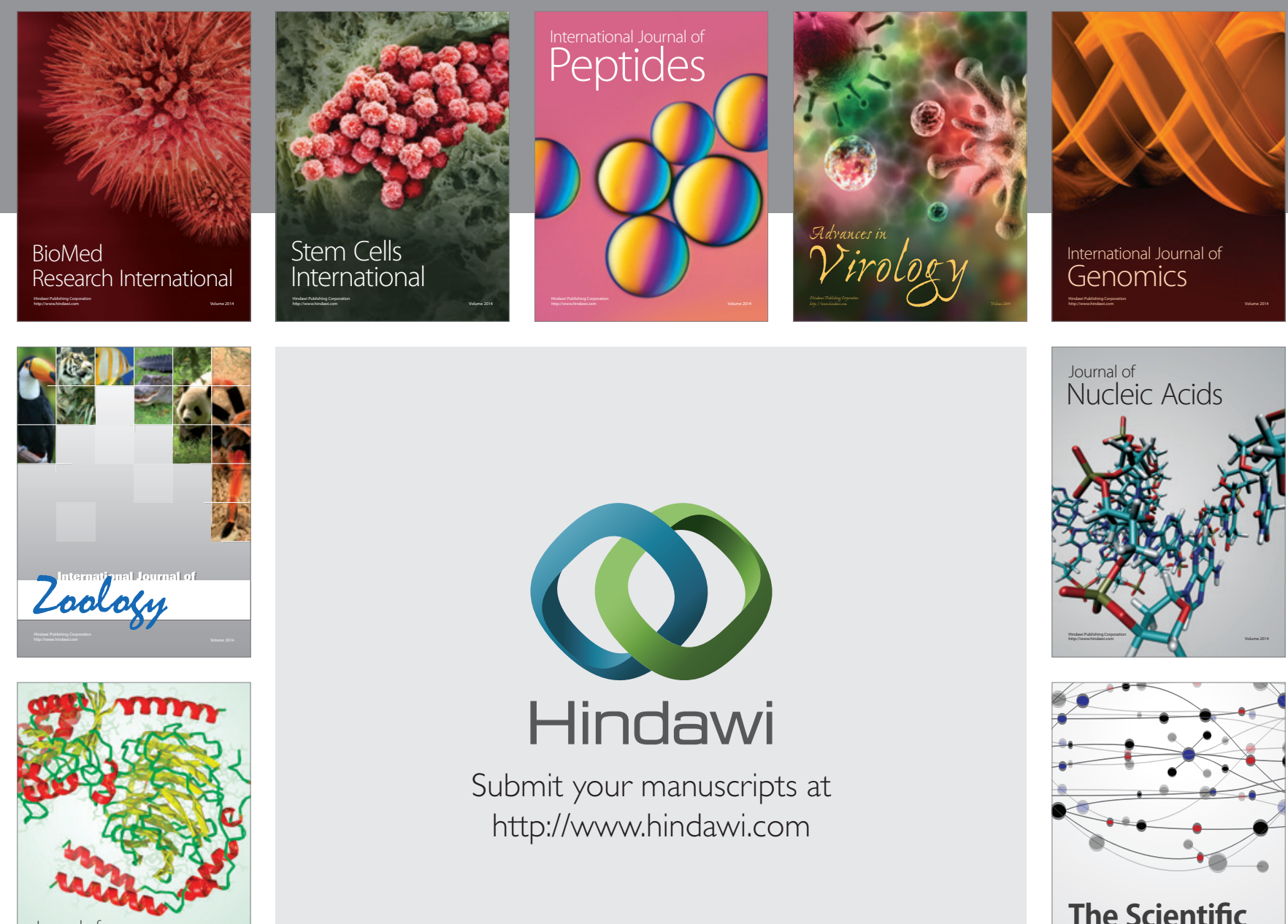

Submit your manuscripts at

http://www.hindawi.com

Journal of
Signal Transduction
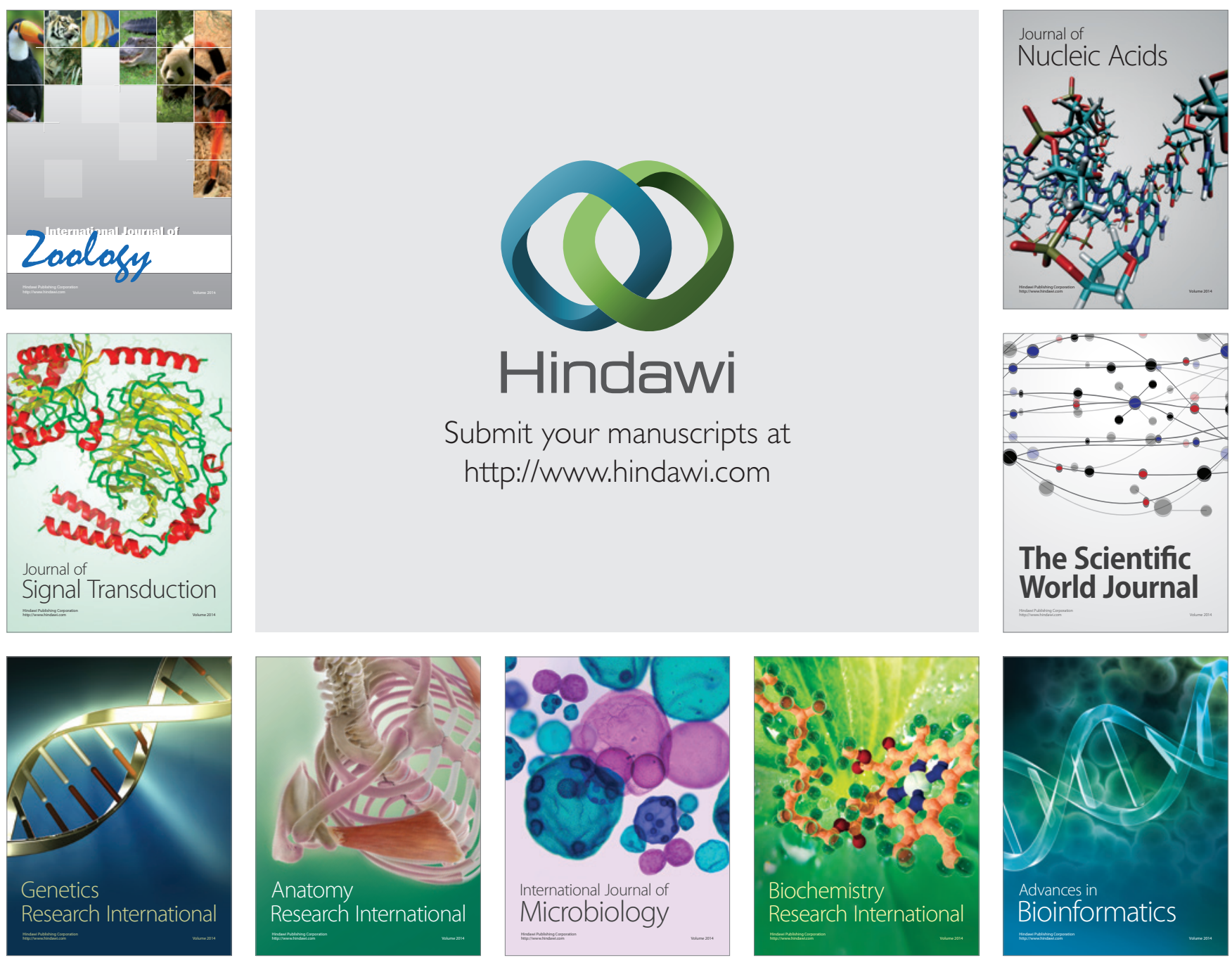

The Scientific World Journal
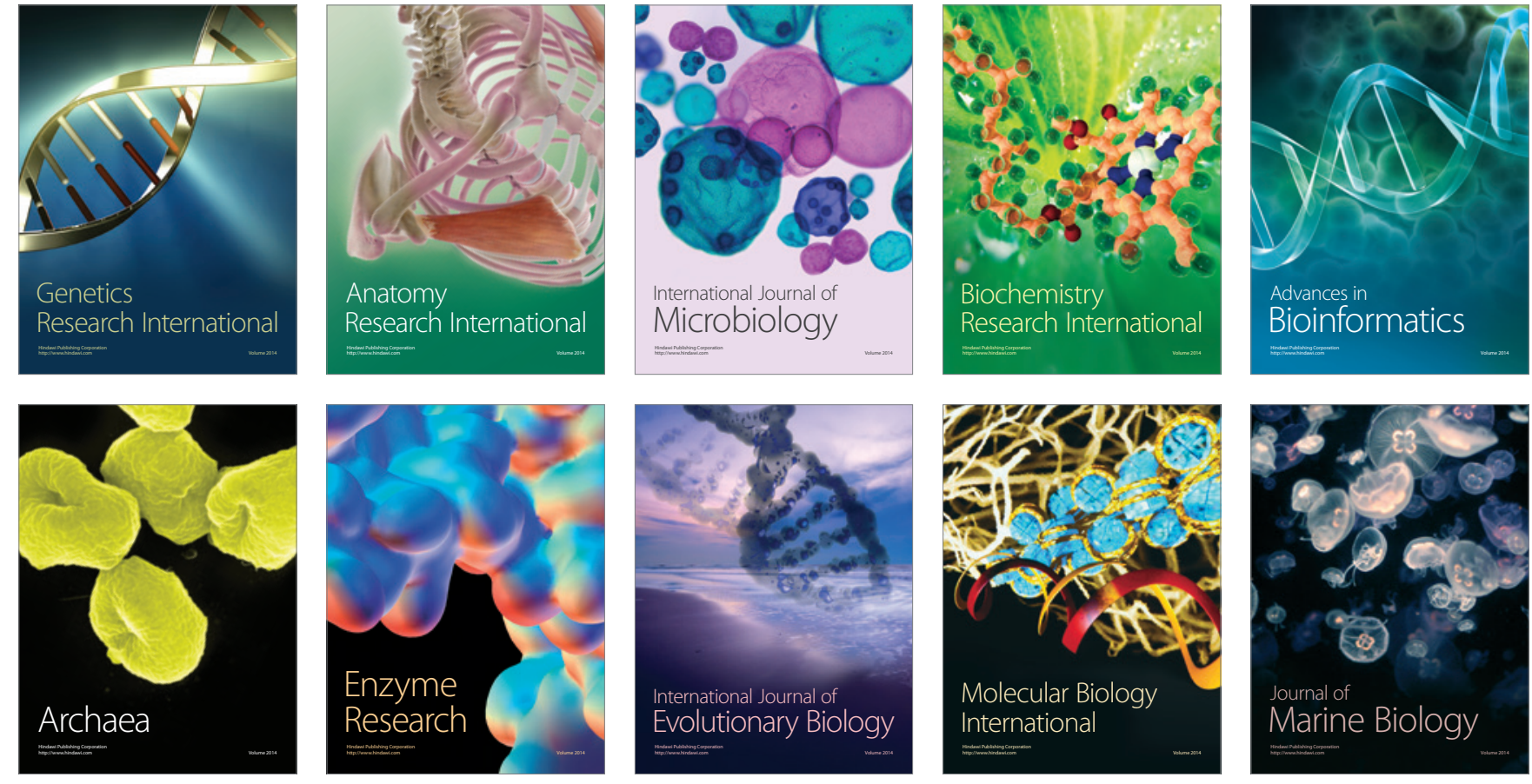